\title{
White's Wilbur and Whiteley's Peter PaUl RUBENS
}

\author{
Juliet McMaster \\ University Professor Emerita, University of Alberta
}

Michael Sims's book called The Story of Charlotte's Web makes no mention of Opal Whiteley or her famous diary, published in 1920. Nevertheless, I want to convince you that Opal Whiteley's diary is a notable part of the story of Charlotte's Web. If I succeed, then Opal Whiteley's diary becomes a striking instance of juvenile writing as a shaping influence on a major work of American literature.

E. B. White, as we all know, cared a great deal about pigs. And before he ever came to write Charlotte's Web, the story of the rescue of a pig from going the way of all porcine flesh, he had come to feel poignantly about the predestined fate of spring pigs. As he wrote in his essay "Death of a Pig,"

The science of buying a spring pig in in blossomtime, feeding it through summer and fall, and butchering it when the cold weather arrives, is a familiar scheme to me and follows an antique pattern. It is a tragedy enacted on most farms with perfect fidelity to the original script. The murder, being premeditated, is in the first degree but quick and skillful, and the smoked bacon and ham provide a ceremonial ending whose fitness is seldom questioned. (Essays 17)

Questioned seldom, but not never. And White's essay, by describing the premature death of a pig from natural causes, shows how its author came to question that familiar script, and to imagine a new script in which the tragic trajectory is bent and redirected by the intervention of a talented and devoted friend: Charlotte, the authorspider.

"Death of a Pig" shows White's familiar artistry—his appealing simple directness that still combines with wry irony. The writer, a no-nonsense unsentimental farmer, can accept and justify the "murder," and make it happen, for his own gain. But when nature intervenes and strikes the pig with a different threat, he is thrust into the new role of nurse. As he works for the pig's life, it becomes a fellow creature rather than bacon-in-the-making. And when the pig dies he grieves genuinely. "The loss we felt was not the loss of ham but the loss of pig" ("Death" 18).

(cc) McMaster. This article is distributed under a Creative Commons Attribution-NonCommercialNoDerivatives 4.0 International Licence (creativecommons.org/licenses/by-nc-nd/4.0/).

Journal of Juvenilia Studies 2.I (2019), Pp. 46-54. DOI: I0.29I73/jjs32 
Juliet McMaster | White's Wilbur and Whiteley's Peter Paul Rubens

Such an experience, it is easy to see, was a catalyst for the creation of Charlotte's $W e b$ some four years later. White wrote about the autobiographical origins of the story. "The idea of the writing of Charlotte's $W e b$ came to me one day when I was on my way down through the orchard carrying a pail of slops to my pig. I had made up my mind to write a children's book about animals, and I needed a way to save a pig's life, and I had been watching a large spider in the backhouse, and what with one thing and another, the idea came to me" (Letters 375). Asked by a man named Wilbur why he had called the pig in the story Wilbur, he responded, "The Wilbur of the book was named not after you but after a pig I used to have named Wilbur. It's that simple" (Letters 375). One can guess that the historical Wilbur was the pig who had died of natural causes, the one who convinced him he "needed a way to save a pig's life."1

That connection is well known. But I suggest that another intertext for Charlotte's $W e b$, and a work that prepared White to receive the message delivered by his sick pig, was a diary by a seven-year-old girl who loved and lost a pig called Peter Paul Rubens.

Born in 1897, some two years ahead of White, Opal Whiteley was a child of the logging camps of Oregon, abused by her mother, and she wrote her diary secretly, with coloured crayons, in a childish script of all capitals, on any scraps of paper she could lay her hands on. At some point the diary was discovered and partially destroyed by her younger sister. As a teenager this gifted child distinguished herself by her nature talks and work with children. In her early twenties, she approached Ellery Sedgwick, editor of the Atlantic Monthly. Sedgwick became interested in the young author and her life, and he asked her if she had ever kept a diary (Sedgwick 255). The diary was sent for, and the multitudinous scraps of script were painstakingly reconstructed, in a process that he witnessed and oversaw.

The Story of Opal: The Journal of an Understanding Heart was published serially in the Atlantic Monthly in 1920, to enormous acclaim. At the time E. B. White was a student and an aspiring journalist at Cornell, working on the Cornell paper the Daily Sun, and it is a sure bet that he was reading the Atlantic, like other literary people of the day. The chronicle of a young girl's response to nature and her relation with animals brought a greatly increased circulation to the Atlantic, and celebrity for the young author. Famous overnight, she and her family were hounded by the media. But then came a backlash, as has happened to other young authors such as Daisy Ashford with the Young Visiters. ${ }^{2}$ The work is too sophisticated, too knowledgeable, too good, so the argument goes, to be the work of a child.

It did not help that Opal had purveyed what we suppose is fantasy as fact: She claimed that she was merely adopted by the Whiteleys, and that her real parents were "Angel Father" and "Angel Mother," who were of the French royal family. Detected in one falsehood, she lost all credibility. Much the same thing happened to Thomas Chatterton, when it was discovered he had invented the mediaeval monk Thomas Rowley. Chatterton took poison and died at seventeen. ${ }^{3}$ Opal survived into her nineties, but her last four decades were spent in a mental hospital. The documentary evidence for the time of writing, however, remained incontrovertible; and Ellery Sedgwick, a man of culture and integrity who had seen the whole process leading to publication, continued to believe in Opal and the genuineness of her remarkable production. $^{4}$ 


\section{JJS July 2019}

Little Opal Whiteley, as we learn from her diary, was a fanatic observer of anniversaries. She seems to have had access to an almanac that provided copious information on the "borning days" and "going-away days" of notable historical figures, from Charlemagne to Tennyson. (In our Juvenilia Press edition of a selection from Opal's diary we were able to date the many events of the narrative.) Her animals, therefore, gathered distinguished names. She calls the calf "with poetry in her tracks" Elizabeth Barrett Browning; the draught horse is William Shakespeare; her pet rat is Thomas Chatterton Jupiter Zeus; and her pig is Peter Paul Rubens, because she first saw him on Rubens's birthday, 29 June. It is he who is the tragic hero of the present essay.

Opal introduces Peter Paul Rubens as "a very plump young pig with a little redribbon squeal, and a wanting to go everywhere I did go" (Whiteley 108). The first incident of the diary that involves him is the day he follows Opal to school, and she does not have the heart to take him back to the pig-pen.

So we just went along to school together.

When we got there, school was already took up. I went in first. The new teacher came back to tell me I was tardy again. She did look out the door. She saw my dear Peter Paul Rubens. She did ask me where that pig came from. I just started in to tell her all about him, from the day I first met him.

She did look long looks at me. She did look those looks for a long time ... I did ask her what she was looking those long looks at me for. She said, "I'm screwtineyesing you." I never did hear that word before-it is a new word. It does have an interest sound. I think I will have uses for it. Now when I am looking long looks at a thing, I will print I did screwtineyes it. (Whiteley 109) ${ }^{5}$

It is easy to see parallels with Charlotte's Web here. Wilbur follows Fern around the place ( $C W 10)$, and Fern like Opal is inattentive at school because she is thinking about her pig ( $C W 7)$. More specific to White's concerns is Opal's sensitivity to words, her tendency to pounce on a new one like "scrutinize" and store it away for future use. Words are treasures for Opal, as they are for White and for Charlotte.

To return to Peter Paul Rubens in the classroom: "It wasn't long until he walked right in. I felt such an amount of satisfaction, having him at school. Teacher felt not so" (109). In fact, teacher is so far from feeling so that she goes after Peter Paul Rubens with a stick; and when Opal defends him she sends them both home. Opal ponders the wide difference between her own response to the pig and teacher's:

Now I have wonders about things. I wonder why was it teacher didn't want Peter Paul Rubens coming to school. Why, he did make such a sweet picture as he did stand in the doorway, looking looks about. And the grunts he gave, they were such nice ones. He stood there saying, "I have come to your school-what class are you going to put me in?" He said in plain grunts the very same words I did say the first day 


\section{Juliet McMaster | White's Wilbur and Whiteley's Peter Paul Rubens}

I came to school. ... But I guess our teacher didn't have understanding of pig talk. (109-110)

Peter Paul Rubens's "plain grunts" are as articulate to Opal as Wilbur's and Charlotte's talk is to Fern, and her teacher's failure to understand "pig talk" is cognate with the adult's usual lack understanding.

It seems that Opal's wisdom filtered through White to Dr. Dorian of Charlotte's Web. When asked if he believes animals talk he responds,

"It is quite possible that an animal has spoken civilly to me and that I didn't catch the remark because I wasn't paying attention. Children pay better attention than grownups. If Fern says the animals in Zukerman's barn talk I'm quite ready to believe her." (CW 110)

Opal certainly pays attention. It is not often that she actually attributes dialogue to animals. But she communicates in one way or another not only with Peter Paul Rubens but also with the shepherd dog and the draught horse and the calf and the crow and the wood-rat and the field-mouse; with sheep and chickens, with wasps and moths, with trees and flowers, and even with lowly potatoes in their "brown dresses" (120). Opal has in abundance what Keats called negative capability: she can suspend her own identity and inhabit that of some other creature. For instance, after a trip in the woods, she discovers a chrysalis in her hair: "I put it to my ear, and I did listen. It had a little voice. It was not a tone voice; it was a heart voice. While I did listen, I did feel its feels. It had lovely ones" (143). That is a child who knows how to pay attention.

In both narratives the composition process is to the fore. Charlotte replaces the old "script" for a pig's existence with a new and saving script, consisting of words laboriously inscribed in a spider's web. Opal's editor Ellery Sedgwick paid attention to the diary's status as a document. He wrote of the "myriad fragments" of the manuscript, the weeks spent "piecing it together, sheet by sheet; each page a kind of picture-puzzle, lettered on both sides in colored chalks, the characters, printed with a child's unskilfulness of hand, nearly an inch high" (Sedgwick, Atlantic, March 290). The volume version included two pages of striking facsimile. Opal herself also brings the "printing" of her record into her account. She prints in the woods, in school, and under the bed where "the mamma" orders her to go in disgrace until she can find time to spank her. Opal's coloured pencils, so essential for figuring out the order of the scraps of paper, are contributed by "the man that wears grey neckties and is kind to mice," as she always calls him. And she is explicit about her ambition to be a writer. "When I grow up," she says, "I am going to write for children-and for grownups that haven't grown up too much" (121).

In the same way White's Charlotte is remarkable for being "both a true friend and a good writer," as the last words of Charlotte's Web emphasise (184). And her most vigorous action consists of her acrobatic feats in creating the letters in her web, "all capitals and no punctuation-much like the inscriptions dug up by archaeologists," as Sedgwick said of Opal's script (Atlantic 249). 


\section{JJS July 2019}

"Now, let's see, the first letter is T," Charlotte soliloquises as she prepares to write "TERRIFIC" in her web. And for a full page we follow her progress in constructing one letter after another, each one larger than herself ( $C W 93 \mathrm{a}-4)$. Janice Alberghene, in discussing Charlotte's writing in the same passage, points out that "the physical practice of writing, routine that it is for adults, is enormously complicated for children. For them, forming letters is analogous to Charlotte's writing" (84). She might have been writing about Opal Whiteley.

Many readers have wondered why Charlotte, who has an excellent vocabulary, should need words for her web supplied by the rat. But Templeton's ferreting around in the dump to find her words on scraps of paper draws attention to the materiality of the composition process, the need for light, paper, pencils, or spinnerets that has to be part of the writer's multiple concerns, as it is both Opal's and Charlotte's. ${ }^{6}$

Opal the child writer, I believe, passes on part of herself both to Fern the child and Charlotte the writer. She has Fern's innocence and lack of power to control the world around her, as well as Charlotte's wisdom and delight in language.

Fern is peripheral to the plot of Charlotte's $W e b$, as many readers have noticed; and White's biographer, Scott Elledge, has shown that the opening that includes her came relatively late in White's composition process (Elledge 295). After her one brave stand against injustice when she saves the runt pig from slaughter, Fern settles for being merely a witness of Wilbur's drama. Since the main work of saving Wilbur from the predestined fate of spring pigs is taken on by Charlotte, one might wonder why White needed Fern at all. White himself explained that the book was virtually finished without her, when he "decided something was wrong, or lacking" (Letters 649). White's step-son Roger Angell similarly recorded that the first version of Charlotte's Web was virtually complete when White set it aside for several months, before rewriting it and enlarging the role of Fern. Late in the day, it seems, White discovered that he needed a way to save a pig's life not just for himself, but for a little girl-eightyear-old Fern, named after a beautiful plant, stands in for seven-year-old Opal, named after a beautiful stone.

"This is the most terrible case of injustice I ever heard of," Fern famously cries as her father takes the axe to slaughter the runt of the litter. "A queer look came over John Arable's face," White wrote memorably. "He seemed almost ready to cry himself' ( $C W$ 3). It is that moment of awakening consciousness, a sudden awareness that pigs matter, that White himself had felt: a moment triggered by a child.

Fern and Opal both baby their pigs. Fern feeds Wilbur with a human baby's bottle and puts a bib on him. Opal likewise adorns her pet pigs with red ribbons and christening robes. Both initially show an ominous lack of anxiety about the destiny of the pig: the Arables are having bacon for breakfast on the morning that Fern protests against the injustice of killing the runt pig; in the diary Opal takes on the massive job of carving the ham intended for "the breakfasts and dinners and suppers of the papa and the mamma" (Whiteley 131) — apparently unaware that the ham is the corpus dilecti of Peter Paul Rubens's predecessor. White the adult is aware that "smoked bacon and ham provide a ceremonial ending to the pig's tragedy," but the little girls who care about pigs are unconscious of the grim irony that connects their breakfasts with the animals they treat as human. 
Juliet McMaster | White's Wilbur and Whiteley's Peter Paul Rubens

Opal learns the hard way. And readers of the diary, who have followed her activities with Peter Paul Rubens and learned to understand how important he is to this child who is constantly rated and beaten by her mother, likewise receive a jolt we are is not likely to forget. I must quote the passage at some length.

I am feeling all queer inside. Yesterday was butchering day. Among the hogs they butchered was Peter Paul Rubens.

The mamma let me go off to the woods all day, after my morning's work was done. Brave Horatius and Lars Porsena of Clusium [the shepherd dog and the crow] went with me ....

We had not gone far, when we heard an awful squeal-so different from the way pigs squeal when they want their supper. I felt cold all over. Then I did have knowings why the mamma had let me start away to the woods without scolding. And I ran a quick run to save my dear Peter Paul Rubens-but already he was dying. And he died with his head in my lap. I sat there feeling dead, too, until my knees were all wet with blood from the throat of my dear Peter Paul Rubens. (Whiteley 155-56)

The shock and the violence are almost unbearable. And the pain is made worse by the fact that Opal had actually been delighted at the unwonted indulgence of being allowed for once to set out on one of her expeditions without being scolded. One is appalled by the bad faith of a mother who tricks her child into believing she has a treat, in order to get her out of the way, and then fails to comfort or protect her from being drenched in her beloved animal's blood. The dose of reality in a hard world is too much. Like White, after reading this passage we are all likely to want to find a way to save a pig's life for a little girl.

There are other notable parallels between the works. Fern's brother Avery, with his casual brutality and stock of weapons, is a milder form of the "chore boy" of the diary, who mocks Opal for her concern for the animals, and deliberately shoots her pet crow in front of her $(152,295)$. When Avery threatens to "knock that ol' spider into this box," Charlotte is saved by the fortunate accident of the breaking of an egg, which fills the air with "terrible gasses and smells" before which both Avery and Fern retreat (72). There is a rotten egg incident in the diary too, when an egg Opal is carrying breaks dramatically, and delivers a "a queer odor that one does have longings to run away from" (316). And I have sometimes wondered whether Templeton's rather aristocratic name may be a distant echo of the grand name Opal gives her wood-rat, Thomas Chatterton Jupiter Zeus.

When Wilbur gets a buttermilk bath before the fair, he comes out "the cleanest, prettiest pig you ever saw" ( $C W 121)$. Likewise when Opal bathes her piglet, he comes out "the pinkest white pig you ever saw" (Whiteley 216). Charlotte and Wilbur devote great care to Charlotte's magnum opus, the egg sac. Opal too is careful and attentive when she finds spider egg-sacs: 


\section{JJS July 2019}

Under that old grey board were five little silk bags. They were white, and they did feel lumps. I know baby spiders will come out of them when comes spring days, because last year I found bags like these, and this year in the spring, baby spiders walked out. They were very figdgety youngsters. (141)

Wilbur too learns about fidgety spider youngsters.

Such incidents, it might be argued, are common occurrences in the rural setting that both authors present. But it is not every narrative of country life that includes a rotten-egg incident and a spider's egg-sac incident, as well as an adopted piglet episode.

The closest affinity between White's fiction and Opal's diary is also the hardest to demonstrate, because it pertains not to words and incidents but to a whole world view. One might claim for both of them the status of nature poets. They are the prose Wordsworths of rural America, recording their epiphanies in the face of a natural world of great beauty and moral force.

The narratives of character and incident include lyric passages that celebrate the earth and the seasons. Characteristically, Whiteley and White do not talk to Nature or its manifestations: no apostrophes to skylarks or wild west winds or nightingales; rather they listen as nature talks to them. Hear each of them on that most evocative of seasons, the fall. This is Opal:

Now are come the days of brown leaves. They fall from the trees; they flutter to the ground. When the brown leaves flutter, they are saying little things. They talk with the wind. I hear them tell of their borning days, when they did come into the world as leaves.... They talked on and on, and I did listen to what they were telling the wind and the earth in their whisperings. (138)

And now White:

The crickets sang in the grasses. They sang the song of summer's ending, a sad, monotonous song. "Summer is over and gone," they sang. "Over and gone, over and gone. Summer is dying, dying."

The crickets felt it was their duty to warn everybody that summertime cannot last forever. Even on the most beautiful days in the whole year, - the days when summer is changing into fall- the crickets spread the rumor of sadness and change. ( $C W 113)$

Such lyric interludes in prose narratives provide a particular rhythm and harmony for both works. Both authors present a knowledge all too intimate with death and pain and loss. Both can incorporate the sadness into a world vision that celebrates life and love, friendship and natural beauty. "Now I think I shall go out the bedroom window and talk to the stars," writes Opal. "They always smile so friendly. This is a very 
wonderful world to live in" (107). "All I hope to say in books," says White, "all that I ever hope to say, is that I love the world" (DiCamillo [v]).

Convinced as I am that E. B. White read and responded to Opal Whiteley's diary, and that his mission to write a story about saving a pig's life arises from his compassion for Peter Paul Rubens as well as from his experience with his own sick pig, I find it sad that he seems never to have acknowledged any admiration for The Story of Opal. It is one more note of sadness in the painful story of an exceptionally gifted child who snatched a temporary fame out of an abused childhood, then suffered another kind of abuse in being accused of falsehood, and sank into insanity and obscurity. After the cooked-up "exposure" of the diary, it was hardly respectable to refer to her. The personal portrait of White that Angell provided suggests that White was diffident about his writing, and perhaps shy of acknowledging a source that had lost credibility ("Andy").

But I do find what I consider to be an implicit acknowledgement, if not an explicit one. For all his success with the New Yorker, White had early been rejected by the high temple of Boston culture, the Atlantic. When his reputation had grown sufficiently, however, the Atlantic came courting him, and invited him to contribute an essay to the issue celebrating its ninetieth anniversary. It was in the journal that brought Peter Paul Rubens to the public that White chose to publish his own story on "The Death of a Pig," which led to the story of the saving of another pig.

\section{NoTES}

${ }^{1}$ For the obvious connection between "Death of a Pig" and Charlotte's Web, see, for instance, Beverley Gherman's biography of White for children, E. B. White: Some Writer!

2 Daisy Ashford's The Young Visiters, written at nine and published in 1919 as edited by James Barrie, sold 230,000 copies in the first two years. But suspicions arose that Barrie of Peter Pan fame must have had a hand in its composition. Having worked on the manuscript, now in the Berg Collection in New York, I have no doubt of its being the true unassisted work of a nine-year-old. The only interventions in the manuscript are the addition of more spelling errors. Although the editor did not invent new errors, he made existing ones, such as "idear" for "idea," consistent. See Jeffrey Mather's introduction to the Juvenilia Press edition of The Young Visiters.

${ }^{3}$ So goes the usual argument, inherited from the Romantics and further purveyed by Henry Wallis's famous 1856 painting of the death of Chatterton, "Cut is the branch that might have grown full straight”. Nick Grooms has suggested, however, that Chatterton's death from arsenic might have been an accidental overdose of a purported cure for venereal disease ("Literary Sleuthing").

4 "Of the rightness and honesty of the manuscript as the Atlantic printed it, I am utterly convinced; more certain am I than of the authorship of many another famous diary, for I have watched the original copy reborn and subjected to the closest scrutiny" (Sedgwick 263).

${ }^{5}$ I quote from Benjamin Hoff's edition, The Singing Creek where the Willows Grow, since it is readily available. His edition is based on the volume, The Story of Opal: The Journal of an Understanding Heart (1920), which includes passages that were omitted from the serial run in the Atlantic. Hoff preserves the sequence of words, but provides his own chapter divisions, paragraphs, and punctuation.

${ }^{6}$ Another contributory text for Charlotte's Web, I believe, is Don Marquis's vers libre serial for the Sun, archy and mehitabel. Archy the poet cockroach, who writes his copy by diving headfirst onto the 


\section{JJS July 2019}

keys of a typewriter, and therefore all in lower case, is surely a forerunner of Charlotte the author spider. And White wrote the introduction to the 1950 Doubleday edition of archy and mehitabel, not long before swinging into the composition of Charlotte's Web (published in 1952). White found the process of writing laborious, and he sympathised with Archy and his author Don Marquis. "Archy's physical limitations (his inability to operate the shift key) relieved Marquis of the troublesome business of capital letters, apostrophes, and quotation marks, those small irritations that slow up all men who are hoping their spirit will soar in time to catch the edition." Indeed Archy becomes for White "blood brother to writing men": "he cast himself with all his force upon a key, head downward. So do we all" (Essays 251). White, Archy, Charlotte and Opal share the heavy duty of creating with words, and manipulating difficult implements to form articulate inscriptions on paper hard to find or in webs fragile and transitory, and subject to the depredations of cats, flies, and little sisters.

\section{WORKS CITED}

Alberghene, Janice M. 'Writing in Charlotte's Web. Critical Essays on E.B. White, edited by Robert L. Root, Jr., G. K. Hall, 1994, pp. 78-87.

Ashford, Daisy. The Young Visiters or Mr Salteena's Plan. Edited by Juliet McMaster and others. Juvenilia Press, 1997. Limited edition.

DiCamillo, Kate. Foreword. Charlotte's Web, by E. B. White, HarperCollins, 2012, pp. [v-vii].

Elledge, Scott. E. B. White: A Biography. W. W. Norton, 1984.

Gherman, Beverly. E. B. White: Some Writer! New York: Beech Tree Paperback, 1994.

Mather, Jeffrey. Introduction. The Young Visiters or Mr. Salteena's Plan, by Daisy Ashford, edited by Juliet McMaster and others, Juvenilia Press, 1997, pp. ixxiv.

Sedgwick, Ellery. “An Opalescent Chapter.” The Happy Profession, Little, Brown, 1946, pp. 252-266.

Sims, Michael. The Story of Charlotte's Web. Walker and Company, 2011.

White, E. B. Charlotte's Web. 1952. HarperCollins, 2012.

. "Death of a Pig." Atlantic Monthly, vol. 181, no. 1, Jan. 1948, pp. 30-33. 90 Anniversary Issue.

—. "Death of a Pig." Essays of E. B. White. Harper and Rowe, 1977, pp. 17-24.

- Letters of E. B. White. Edited byDorothy Lobrano Guth, Harper and Rowe, 1977, pp. 17-24.

Whiteley, Opal. Peter Paul Rubens and Other Friendly Folk. Edited by Laura Cappello, Juliet McMaster, Lesley Peterson, and Chris Wangler, Juvenilia Press, 2001.

—. The Singing Creek Where the Willows Grow: The Mystical Nature Diary of Opal Whiteley, Biography and Afterword by Benjamin Hoff, Penguin Books, 1994.

- The Story of Opal: The Journal of an Understanding Heart. Atlantic Monthly Press, 1920. 